said last week that the two bodies were "not interchangeable".

The council, announced last week by Mr. Anthony Crosland, Secretary of State for Education and Science, has all embracing terms of reference. Its chief function will be to advise bodies concerned with education and training about audio-visual aids, and this advice will include government departments. In addition the council will hold a watching brief in the work going on in educational technology, encourage research and development, collect and distribute information, and promote the training of staff to make use of the aids. Finally, it is charged with advising the Secretaries of State whether a national centre is needed, and what its functions and structure should be; in view of Dr. Brynmor-Jones's well known position on this issue, it is reasonable to guess that the council will indeed recommend that the centre should be set up.

The problem, according to $\mathrm{Mr}$. Crosland, is financial; the centre would cost $£ 350,000$ in capital and $£ 260,000$ in recurrent costs. While the financial support for the council is undecided, it will not be of the same order as this-nor, most likely, will be the benefits. The council will have about twenty to twenty-five members, from schools, universities, colleges, industry and the services. It will also include representatives from the British Broadcasting Corporation and the Independent Television Authority, and two or three at least from Scotland.

In addition to the advisory role, Dr. Brynmor-Jones also hopes to promote audio-visual aids. This is really more important, as there is still some hostility among teachers, and Mr. Crosland has had a bellyful of good advice already. The danger is that the council will labour mightily for months or years, and then come up with advice new to nobody. It is hard to see, in fact, what the new council can do that could not have been done by a combination of the existing agencies, given government support on a similar scale.

\section{Sanctions Bite}

THE political turmoil in central Africa has claimed another victim-the Agricultural Research Council of Central Africa, a joint council covering Rhodesia, Zambia and Malawi. Set up while the Central African Federation still survived in 1963 , the council has been in difficulties since the unilateral declaration of independence by Rhodesia. The annual report for 1965 foreshadowed the break up of the council: "The major danger is that this new scientific structure, which is, inevitably, vulnerable to financial sanctions, should be destroyed accidentally by the British Government's measures against Rhodesia".

In fact the failure was precipitated by Zambia, which announced that it intended to withdraw from the council on June 30, 1967. The British Government, which had been supporting the council to the tune of $£ 100,000$ per year, declined to continue this support for Malawi and Rhodesia alone. The council has therefore decided to cease operations by the end of 1967. Each country will need to make its own arrangements to continue or discontinue the work of the council, and to some extent this will doubtless depend on continued support from foundations and other organizations, which supplied $£ 152,000$ last year. The council has been operating ten research teams, made up of 50 graduates and more than 200 assistants, and the principal lines of research have included reproduction in beef cattle, biological control of tsetse flies, tracing of underground water supplies, and research into ground nuts, cotton pest, and soil fertility. These are projects which underdeveloped countries can ill afford to lose.

\section{Commonwealth Scientists Confer}

To judge from the agenda, the conference of commonwealth scientists held from April 7 to 11 covered a lot of ground. Eighty scientists from twenty-five commonwealth countries, meeting in Merton College, Oxford, spent some time discussing the problems of those less fortunately situated. They also heard reviews of the Royal Society's commonwealth activities, and discussed universities and scientific education, scientific policy and organization, and commonwealth co-operation in research projects.

In underdeveloped countries, it was agreed, scientists should stick to the problems nearest home. Dr. Atma Ram, Director General of the Department of Scientific and Industrial Research in India, sensibly declared that it is more important to have technological competence than to strive after technological independence. Such competence is best directed towards agricultural science. As for aid, there should be more of it, and what there is should be more selective, and should be distributed according to the wishes of the recipient rather than the donor. None of this need surprise anybody, and perhaps it was the difficulty of getting to grips with problems expressed in such general terms that led to a suggestion that more specialized conferences should be held.

Not all the discussion, however, was as diffuse as this. Delegates showed considerable enthusiasm for some more detailed proposals, among them examiners from abroad and "twinning" arrangements between science departments. The old emphasis on interchange between the United Kingdom and the commonwealth seems to be giving way to a more general interchange of personnel, and this was a source of satisfaction. The setting up of centres in developing countries to which scientists could go for perhaps four months in the year, taking their families and being assured of a desk and a laboratory to work in, was another project which found general approval. To prove that commonwealth co-operation in science is alive and kicking, a session was devoted to examining joint projects such as the International Biological Programme and Antarctic research. The enthusiasm shown indicates a need for more conferences of this sort; possibly more specialist and certainly more frequent--the last was held in 1946, and very few participants could remember it.

\section{Money for Teesdale}

THe discreet confirmation by Imperial Chemical Industries, Ltd., that they will indeed be giving $£ 100,000$ for research into the botany of Teesdale makes an interesting comparison with their original strident announcement while the decision about the reservoir was still in doubt. Now that the Bill to build the reservoir at Cow Green has obtained the Royal Assent, plans for the study have gone ahead. 